\title{
$B R A F$ and endocrine tumors: mutations are frequent in papillary thyroid carcinomas, rare in endocrine tumors of the gastrointestinal tract and not detected in other endocrine tumors
}

\author{
A Perren, S Schmid, T Locher, P Saremaslani, C Bonvin, P U Heitz \\ and $P$ Komminoth ${ }^{1}$
}

Institute for Clinical Pathology, Department of Pathologie, University Hospital Zürich, Schmelzbergstr. 12, $\mathrm{CH}-8091$, Switzerland

${ }^{1}$ Institut for Clinical Pathology, Kantonsspital Baden, Switzerland

(Requests for offprints should be addressed to A Perren; Email: Aurel.Perren@usz.ch)

\begin{abstract}
The tumorigenesis of sporadic endocrine tumors is still not fully understood. Activating point mutations of the serine/threonine kinase gene BRAF located on 7q34 are found in a wide range of malignancies, with the highest frequency $(66 \%)$ occurring in malignant melanomas. Melanomas are tumors of neuralcrest-derived cells as are medullary thyroid carcinomas, pheochromocytomas and paragangliomas. $B R A F$ has not been examined in endocrine tumors of the diffuse neuroendocrine system or of neuralcrest-derived cells.

We examined 130 endocrine tumors of the pancreas, parathyroid gland, adrenal medulla, paraganglia, lung and gastrointestinal tract as well as follicular and c-cell-derived thyroid tumors. We found a high rate of V559E mutations in papillary thyroid carcinomas (47\%), one V599E mutation in a well-differentiated gastric endocrine carcinoma (malignant carcinoid), but no activating BRAF mutations in all other endocrine tumors examined. These results point towards different pathways in tumorigenesis of endocrine tumors of various localizations and only rare involvement of the MAP kinase (MAPK) pathway in a subset of malignant neuroendocrine tumors.
\end{abstract}

Endocrine-Related Cancer (2004) 11 855-860

\section{Introduction}

Activating mutations of the serine/threonine kinase gene $B R A F$ located on chromosome $7 \mathrm{q} 34$ have recently been reported in a wide range of malignancies, with the highest frequency $(66 \%)$ occurring in malignant melanomas (Davies et al. 2002). The described mutations are clustered in exons 11 and 15 and are located in the G-loop or activation segment of the gene. It was shown that transient transfection with ${ }^{\mathrm{V} 599 \mathrm{E}} B R A F$ leads to a 10-fold increase of basal kinase activity and downstream activation of the MAP kinase (MAPK) pathway (Davies et al. 2002). The V599E mis-sense mutation in exon 15 is found in more than $90 \%$ of mutated malignant melanomas (Davies et al. 2002). Interestingly, thus far no analyses of endocrine tumors have been conducted (with the exception of thyroid tumors), although there are several indications pointing towards a possible role of $B R A F$ in this type of tumor also. First, like melanomas (Dupin \& Le Douarin 2003), a subset of endocrine tumors including pheochromocytomas (PCCs), paragangliomas (PGLs) and medullary thyorid carcinomas (MTCs) evolve from neural-crest-derived cells (Pasini et al. 1996). Secondly, on a molecular genetic level, activation of tyrosine kinases (Ret mutations in MTCs and PCCs, Ret/PTC translocations or TM3/NTRK1 rearrangements producing the TRK oncogene in papillary thyroid carcinomas (PTCs) are known to be of importance at least in a subset of endocrine tumors. Thirdly, chromosomal gains of 7q34 have repeatedly been described in endocrine tumors, possibly an alternative mechanism leading to 
increased BRAF activity due to increased protein expression. More specifically, comparative genomic hydridization $(\mathrm{CGH})$ studies have demonstrated gains of $7 \mathrm{q}$ in up to $66 \%$ of follicular thyroid carcinomas (FTCs) (Roque et al. 1999, Perissel et al. 2002), 30\% of pancreatic endocrine tumors (PETs) (Speel et al. 1999, 2001, Stumpf et al. 2000), $10 \%$ of parathyroid adenomas (PTAs) (Agarwal et al. 1998), gastrointestinal neuroendocrine tumors (GI-NETs) (Zhao et al. 2000), bronchial neuroendocrine tumors (BNETs) (Zhao et al. 2000) and PGLs (Edstrom et al. 2000) and $5 \%$ of papillary thyroid carcinomas (PTC) (Singh et al. 2000). We therefore investigated a series of 130 endocrine tumors of different organs for $B R A F$ alterations in exons 11 and 15 .

\section{Materials and Methods}

\section{Tumor samples}

Fresh frozen tissue and paraffin blocks were obtained from the files of the Department of Pathology, University Hospital Zurich. A total of 130 tumors were examined including 25 PETs, 10 PTAs, 16 PCCs (all without Ret mutations), 18 PGLs, 8 B-NETs and 6 GI-NETs (carcinoids, CDs), 25 MTCs (including one multiple endocrine neoplasia type 2a (MEN2a)-associated tumor, 7 tumors with somatic Ret exon 16 mutations and 13 tumors without Ret mutation), 7 FTCs and 15 PTCs. Tumor samples and corresponding normal tissue had been snap-frozen in liquid nitrogen after surgical removal and stored at $-80^{\circ} \mathrm{C}$. Where no fresh tissue was available, paraffin blocks of tumor and non-neoplastic tissue were used. These tissue samples had been fixed in $4 \%$ buffered formalin and embedded in paraffin according to standard protocols.

\section{Controls}

Tumor DNA of a paraffin-embedded malignant melanoma with known BRAF V599E mutation was used as positive control; blood DNA of a healthy individual served as negative control.

\section{Denaturing gradient gel electrophoresis (DGGE)-based mutation analysis}

DNA from fresh frozen tissue was extracted using the Purgene-kit (GentraSystems, Minneapolis, MN, USA) according to the manufacturer's recommendations. Where no frozen tissue was available, tumor and normal tissue were micro-dissected from $10 \mu \mathrm{m}$ tissue sections of paraffin blocks and the DNA extracted as previously described (Perren et al. 1998).

PCR using genomic DNA as template was carried out in a $50 \mu 1$ mixture of $1 \times$ PCR buffer (Perkin Elmer Europe,
Table 1 Primers used

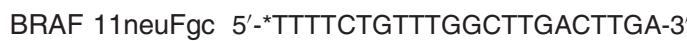

BRAF 11 Rgc 5 '-gcgcgCGAACAGTGAATATTTCCTTTGAT-3

BRAF $15 \mathrm{FgC} \quad 5^{\prime}$-ggcgcTCATAATGCTTGCTCTGATAGGA-3'

BRAF 15 Rgc 5'-*GGCCAAAAATTTAATCAGTGGA-3'

${ }^{*}$ cgcccgccgegeccogegccoggccogccgcccccgcccgaaataataaa

Rotkreuz, Switzerland) containing $400 \mathrm{ng}$ of template DNA, $200 \mu \mathrm{M}$ dNTP (Roche), $1 \mu \mathrm{M}$ of each intron-based primer (Table 1) and $1 \mu \mathrm{l}$ Taq Polymerase (Ampli Taq Gold, Perkin Elmer Europe). A 'touch-down' procedure was used consisting of denaturation for $5 \mathrm{~s}$ at $95^{\circ} \mathrm{C}$, annealing for $60 \mathrm{~s}$ at temperatures decreasing from 60 to $55^{\circ} \mathrm{C}$ during the first 11 cycles (with $0.5^{\circ} \mathrm{C}$ decremental steps in cycles 2 to 11), and ending with an extension step at $72{ }^{\circ} \mathrm{C}$ for $60 \mathrm{~s}$. Ten cycles with an annealing temperature of $55^{\circ} \mathrm{C}$ and 15 cycles with an annealing temperature of $45^{\circ} \mathrm{C}$ followed with extension times of $90 \mathrm{~s}$. After a final extension for $10 \mathrm{~min}$ at $72^{\circ} \mathrm{C}$, heteroduplex formation was induced by initial denaturation for $10 \mathrm{~min}$ at $98^{\circ} \mathrm{C}$ followed by incubations at $55^{\circ} \mathrm{C}$ for $30 \mathrm{~min}$ and $37^{\circ} \mathrm{C}$ for $30 \mathrm{~min}$. For DGGE, $10 \mu \mathrm{l}$ of the PCR product in $3 \mu \mathrm{l}$ Ficoll-based loading buffer were loaded onto $10 \%$ polyacrylamide gels containing a urea-formamide gradient in $0.5 \times$ Tris-acetate TAE-EDTA. The amplicons were electrophoresed at $60{ }^{\circ} \mathrm{C}$ and $100 \mathrm{~V}$ for $16 \mathrm{~h}$. DNA strands were visualized using silver staining as described previously (Komminoth et al. 1994). All samples were additionally cycle sequenced using an automated sequencer (Model 373A, Applied Biosystems, Foster City, CA, USA) and the Sequencher v.3.1.1 (Gene Codes Corp., Ann Arbor, MI, USA) software.

\section{Results}

$B R A F$ exon 15 mutations were detected in 7 of 15 PTCs $(47 \%)$. All mutations consisted of a thymidine to adenine exchange at nucleotide 1769 resulting in a valine to glutamate substitution of residue 599 (V599E). A representative DGGE gel and the sequence result is shown in Fig. 1.

In all 7 PTCs the V599E mutation was somatic in nature, thus it was absent in the germline DNA of the patients. Exon 11 mutations were absent in the 15 PTCs tested.

One gastric, well-differentiated endocrine carcinoma (malignant carcinoid) with liver metastasis showed a somatic BRAF V599E mutation, no alterations were detected in the remaining 5 gastrointestinal CDs.

No alterations indicative for mutations of $B R A F$ exon 11 and 15 were identified in any of the 25 PETs, 10 PTAs, 16 PCCs, 18 PGLs, 25 MTCs, 7 FTCs and 8 bronchial CDs tested. The results are summarized in Table 2. 


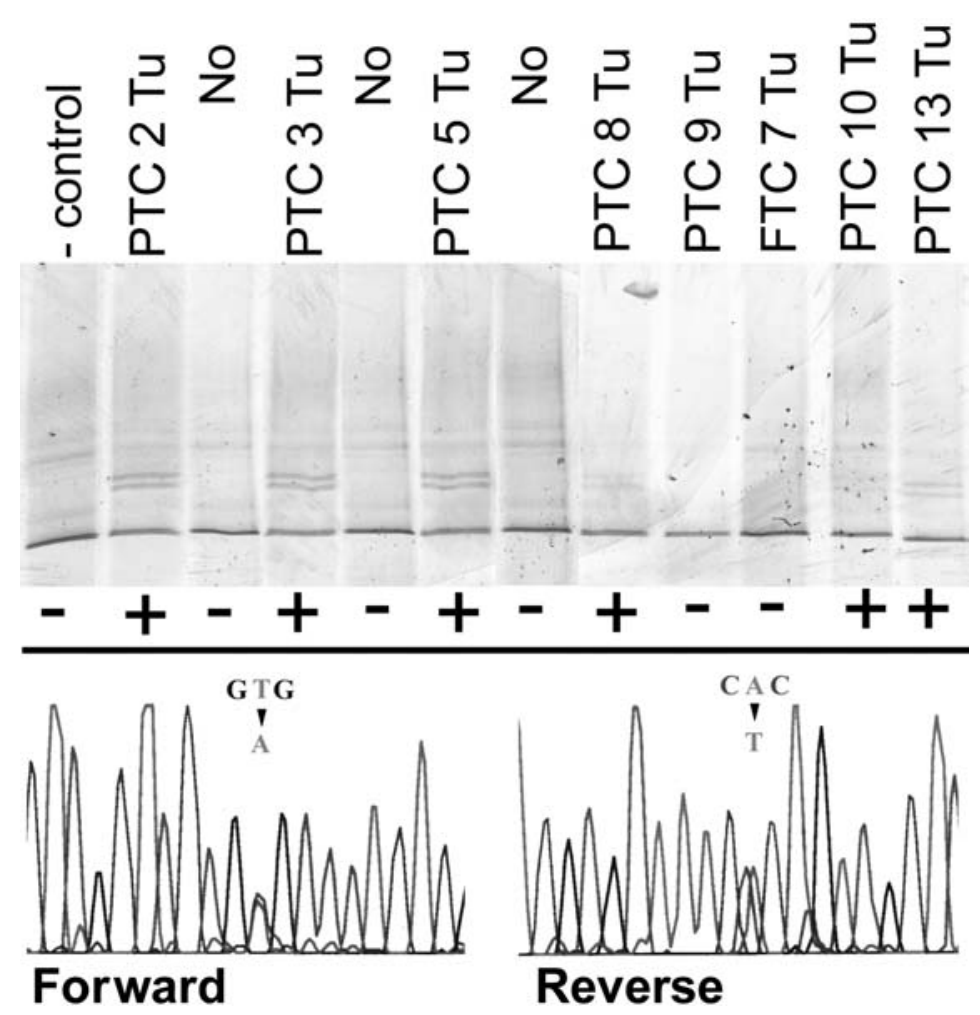

Figure 1 Top, DGGE pattern of BRAF exon 15. Samples marked '+' show an abnormal banding pattern. Bottom, the corresponding sequence analysis shows a heterozygous V599E mutation. Tu: Tumor; No: normal non neoplastic tissue.

\section{Discussion}

We describe a high rate of somatic $B R A F$ exon 15 mutations in PTCs of classical type. All these $B R A F$ mutations were somatic as the sequence of the corresponding normal tissues was wild-type. These results are in agreement with reports, published during completion of this study, which described the same type of $B R A F$ exon 15 mutation in 36-69\% of PTCs (Cohen et al. 2003, Fukushima et al. 2003, Kimura et al. 2003, Namba et al. 2003, Nikiforova et al. 2003, Soares et al. 2003, Xu et al. 2003, Puxeddu et al. 2004, Soares et al. 2004, Trovisco et

Table 2 Mutations present in endocrine tumors

\begin{tabular}{lllll}
\hline & & & Mutation & \\
\cline { 3 - 5 } Tumor & $\begin{array}{l}\text { No. of } \\
\text { tumors }\end{array}$ & Braf 11 & Braf 15 & net 16 \\
\hline PET $^{*}$ & 25 & $0 / 22$ & $0 / 25$ & n.a. \\
CD lung & 8 & $0 / 8$ & $0 / 8$ & n.a. \\
CD gi & 6 & $0 / 6$ & $1 / 6$ & n.a. \\
PTA & 10 & $0 / 10$ & $0 / 10$ & $0 / 13$ \\
PCC & 16 & $0 / 16$ & $0 / 16$ & n.a. \\
PGL & 18 & $0 / 18$ & $0 / 18$ & n.a. \\
PTC & 15 & $0 / 15$ & $7 / 15$ & n.a. \\
FTC & 7 & $0 / 7$ & $0 / 7$ & $7 / 20$ \\
MTC & 25 & $0 / 25$ & $0 / 24$ & $8 / 129$ \\
Total
\end{tabular}

PET, pancreatic endocrine tumor (*including 3 MEN1-associated PETs); CD lung, bronchial neuroendocrine tumors (carcinoids); CD gi, gastrointestinal neuroendocrine tumors (carcinoids); PTA, parathyroid adenoma; PCC, pheochromocytoma; PGL, paragangliomas; PTC, papillary thyroid carcinoma; FTC, follicular thyroid carcinoma; MTC, medullary thyroid carcinoma ${ }^{* *}$ including 1 MEN2a-associated MTC); ${ }^{* *}$ numbers do not add up, some exons could not be amplified by PCR. 
al. 2004, Xing et al. 2004). Thus, the pathway of PTCs appears to be elucidated since either a tyrosin kinase receptor (Ret/PTC translocation, TRK mutation) or the downstream tyrosin kinase BRAF are affected on a genetic level.

$B R A F$ is a member of the MAPK pathway inducing a mitogenic response upon stimulation of tyrosine kinase receptors (Liebmann 2001). In colon carcinomas, BRAF mutations were only found in tumors without $K-R A S$ mutations, indicating an equivalent tumorigenic effect (Davies et al. 2002, Rajagopalan et al. 2002). A similar exclusive correlation was observed in PTCs for $B R A F$ mutations and Ret/PTC translocations. Kimura et al. (2003) and Soares et al. (2003) showed no overlap between tumors with Ret/PTC translocation, BRAF or RAS mutations in 78 and 50 PTCs respectively, indicating that in PTCs the two alterations lead to very similar downstream effects. Our series included one PTC with an inactivating PTEN mutation and concomitant loss of PTEN protein expression (Dahia et al. 1997, Gimm et al. 2000), but no BRAF exon 15 mutation. As BRAF is known to be downstream of $\mathrm{G}$ protein-coupled receptor (GPCR) signaling (Liebmann 2001), the inactivating mutation of the tumor suppressor PTEN could lead to a similar downstream effect.

The work presented is the first study examining $B R A F$ in endocrine tumors other than PTCs and FTCs. We detected one somatic BRAF V599E mutation in a metastasizing endocrine tumor of the stomach (malignant carcinoids). This is evidence for a rare involvement of the MAPK pathway in these tumors. The fact that a malignant endocrine tumor bears this mutation might be indicative for an event of tumor progression. Interestingly, we previously described a similar phenomenon of a PET harboring a PTEN mutation (Perren et al. 2000) which also turned out to be of a malignant phenotype.

The absence of $B R A F$ exon 11 and 15 mutations in all other examined types of endocrine tumors - including the neural-crest-derived MTC, PGL and PCC — seems interesting. In addition to MEN2-associated familial MTC, PCC and PTA, a subset of sporadic forms of the first two tumors are also known to harbor activating Ret tyrosine kinase receptor mutations (Komminoth et al. 1995, van der Harst et al. 1998). However, we did not detect any $B R A F$ mutation in sporadic MTCs, PCCs and PGLs. The Ret mutation status of the MTCs and PCCs of this study was known and 7 MTC samples with somatic Ret M918T mutation as well as one MEN2a (C634Y)associated MTC were included (Table 2). Somatic or germline Ret mutations were absent in all 13 informative PCC samples. Therefore BRAF mutations are absent in these tumors irrespective of Ret mutation status. These data are indirect evidence that signaling of the constitu- tively active forms of mutated Ret differs from Ret/PTC translocation induced signaling. In neural-crest-derived tumors, pathways other than the MAPK downstream pathway of Ret seem to be of importance. On the other hand, FTCs are more likely to harbor $R A S$ mutations than PTCs; however, we and others could not detect any $B R A F$ V599E mutation in FTCs.

In summary our study confirms a high rate of $B R A F$ V559E mutations in PTCs. We detected a single V599E mutation in a metastasizing gastric endocrine carcinoma which might point towards a role of the MAPK pathway in malignant transformation of these tumors. $B R A F$ mutations were absent in all neural-crest-derived tumors including MTCs, PCCs and PGLs. As a subset of these tumors is known to contain activating Ret mutations, our results indicate that pathways other than the MAPK pathway are downstream targets of Ret mutations in these tumors.

\section{Funding}

This study was supported in part by the Swiss National Science Foundation (SNF 31-61884.00) and the Swiss Cancer League (KFS-00997-02-2000). There is no conflict of interest that would prejudice the impartiality of the research.

\section{References}

Agarwal SK, Schrock E, Kester MB, Burns AL, Heffess CS, Ried T \& Marx SJ 1998 Comparative genomic hybridization analysis of human parathyroid tumors. Cancer Genetics and Cytogenetics 106 30-36.

Cohen Y, Xing M, Mambo E, Guo Z, Wu G, Trink B, Beller U, Westra WH, Ladenson PW \& Sidransky D 2003 BRAF mutation in papillary thyroid carcinoma. Journal of the National Cancer Institute 95 625-627.

Dahia PL, Marsh DJ, Zheng Z, Zedenius J, Komminoth P, Frisk T, Wallin G, Parsons R, Longy M, Larsson C et al. 1997 Somatic deletions and mutations in the Cowden disease gene, PTEN, in sporadic thyroid tumors. Cancer Research 57 4710-4713.

Davies H, Bignell GR, Cox C, Stephens P, Edkins S, Clegg S, Teague J, Woffendin H, Garnett MJ, Bottomley W et al. 2002 Mutations of the BRAF gene in human cancer. Nature $\mathbf{4 1 7}$ 949-954.

Dupin E \& Le Douarin NM 2003 Development of melanocyte precursors from the vertebrate neural crest. Oncogene 22 3016-3023.

Edstrom E, Mahlamaki E, Nord B, Kjellman M, Karhu R, Hoog A, Goncharov N, Teh BT, Backdahl M \& Larsson C 2000 Comparative genomic hybridization reveals frequent losses of chromosomes $1 \mathrm{p}$ and $3 \mathrm{q}$ in pheochromocytomas and abdominal paragangliomas, suggesting a common genetic etiology. American Journal of Pathology 156 651-659. 
Fukushima T, Suzuki S, Mashiko M, Ohtake T, Endo Y, Takebayashi Y, Sekikawa K, Hagiwara K \& Takenoshita S 2003 BRAF mutations in papillary carcinomas of the thyroid. Oncogene 22 6455-6457.

Gimm O, Perren A, Weng LP, Marsh DJ, Yeh JJ, Ziebold U, Gil E, Hinze R, Delbridge L, Lees JA et al. 2000 Differential nuclear and cytoplasmic expression of PTEN in normal thyroid tissue, and benign and malignant epithelial thyroid tumors. American Journal of Pathology 156 1693-1700.

Kimura ET, Nikiforova MN, Zhu Z, Knauf JA, Nikiforov YE \& Fagin JA 2003 High prevalence of BRAF mutations in thyroid cancer: genetic evidence for constitutive activation of the RET/PTC-RAS-BRAF signaling pathway in papillary thyroid carcinoma. Cancer Research 63 1454-1457.

Komminoth P, Kunz E, Hiort O, Schroder S, Matias-Guiu X, Christiansen G, Roth J \& Heitz PU 1994 Detection of RET proto-oncogene point mutations in paraffin-embedded pheochromocytoma specimens by nonradioactive singlestrand conformation polymorphism analysis and direct sequencing. American Journal of Pathology 145 922-929.

Komminoth P, Kunz EK, Matias-Guiu X, Hiort O, Christiansen G, Colomer A, Roth J \& Heitz PU 1995 Analysis of RET protooncogene point mutations distinguishes heritable from nonheritable medullary thyroid carcinomas. Cancer 76 479-489.

Liebmann C 2001 Regulation of MAP kinase activity by peptide receptor signalling pathway: paradigms of multiplicity. Cellular Signalling 13 777-785.

Namba H, Nakashima M, Hayashi T, Hayashida N, Maeda S, Rogounovitch TI, Ohtsuru A, Saenko VA, Kanematsu T \& Yamashita S 2003 Clinical implication of hot spot BRAF mutation, V599E, in papillary thyroid cancers. Journal of Clinical Endocrinology and Metabolism 88 4393-4397.

Nikiforova MN, Kimura ET, Gandhi M, Biddinger PW, Knauf JA, Basolo F, Zhu Z, Giannini R, Salvatore G, Fusco A et al. 2003 BRAF mutations in thyroid tumors are restricted to papillary carcinomas and anaplastic or poorly differentiated carcinomas arising from papillary carcinomas. Journal of Clinical Endocrinology and Metabolism $\mathbf{8 8}$ 5399-5404.

Pasini A, Michiels FM, Chappuis-Flament S, Geneste O, Rossel M, Fournier L, Feunteun J, Lenoir G, Schuffenecker I \& Billaud M 1996 Neural crest and multiple endocrinopathies. Comptes rendus des seances de la Societe de biologie et de ses filiales 190 557-567.

Perissel B, Bernheim A, Couturier J, Fouilhoux G, Vago P \& Oncologique GF 2002 De la cytogenetique a la cytogenomique des tumeurs de la thyroide. Bulletin du Cancer 89 588-592.

Perren A, Roth J, Muletta-Feurer S, Saremaslani P, Speel EJ, Heitz PU \& Komminoth P 1998 Clonal analysis of sporadic pancreatic endocrine tumours. Journal of Pathology 186 363-371.

Perren A, Komminoth P, Saremaslani P, Matter C, Feurer S, Lees JA, Heitz PU \& Eng C 2000 Mutation and expression analyses reveal differential subcellular compartmentalization of PTEN in endocrine pancreatic tumors compared to normal islet cells. American Journal of Pathology 157 1097-1103.
Puxeddu E, Moretti S, Elisei R, Romei C, Pascucci R, Martinelli M, Marino C, Avenia N, Rossi ED, Fadda G et al. 2004 BRAF(V599E) mutation is the leading genetic event in adult sporadic papillary thyroid carcinomas. Journal of Clinical Endocrinology and Metabolism 89 2414-2420.

Rajagopalan H, Bardelli A, Lengauer C, Kinzler KW, Vogelstein B \& Velculescu VE 2002 Tumorigenesis: RAF/ RAS oncogenes and mismatch-repair status. Nature 418934.

Roque L, Serpa A, Clode A, Castedo S \& Soares J 1999 Significance of trisomy 7 and 12 in thyroid lesions with follicular differentiation: a cytogenetic and in situ hybridization study. Laboratory Investigations $\mathbf{7 9}$ 369-378.

Singh B, Lim D, Cigudosa JC, Ghossein R, Shaha AR, Poluri A, Wreesmann VB, Tuttle M, Shah JP \& Rao PH 2000 Screening for genetic aberrations in papillary thyroid cancer by using comparative genomic hybridization. Surgery 128 888-893 (discussion, 893-894).

Soares P, Trovisco V, Rocha AS, Lima J, Castro P, Preto A, Maximo V, Botelho T, Seruca R \& Sobrinho-Simoes M 2003 BRAF mutations and RET/PTC rearrangements are alternative events in the etiopathogenesis of PTC. Oncogene 22 4578-4580.

Soares P, Trovisco V, Rocha AS, Feijao T, Rebocho AP, Fonseca E, Vieira de Castro I, Cameselle-Teijeiro J, CardosoOliveira M \& Sobrinho-Simoes M 2004 BRAF mutations typical of papillary thyroid carcinoma are more frequently detected in undifferentiated than in insular and insular-like poorly differentiated carcinomas. Virchows Archiv $\mathbf{4 4 4}$ 572-576.

Speel EJ, Richter J, Moch H, Egenter C, Saremaslani P, Rutimann K, Zhao J, Barghorn A, Roth J, Heitz PU et al. 1999 Genetic differences in endocrine pancreatic tumor subtypes detected by comparative genomic hybridization. American Journal of Pathology 155 1787-1794.

Speel EJ, Scheidweiler AF, Zhao J, Matter C, Saremaslani P, Roth J, Heitz PU \& Komminoth P 2001 Genetic evidence for early divergence of small functioning and nonfunctioning endocrine pancreatic tumors: gain of 9Q34 is an early event in insulinomas. Cancer Research 61 5186-5192.

Stumpf E, Aalto Y, Hoog A, Kjellman M, Otonkoski T, Knuutila S \& Andersson LC 2000 Chromosomal alterations in human pancreatic endocrine tumors. Genes, Chromosomes and Cancer 29 83-87.

Trovisco V, Vieira de Castro I, Soares P, Maximo V, Silva P, Magalhaes J, Abrosimov A, Guiu XM \& Sobrinho-Simoes M 2004 BRAF mutations are associated with some histological types of papillary thyroid carcinoma. Journal of Pathology 202 247-251.

van der Harst E, de Krijger RR, Bruining HA, Lamberts SW, Bonjer HJ, Dinjes WN, Proye C, Koper JW, Bosman FT, Roth J et al. 1998 Prognostic value of RET proto-oncogene point mutations in malignant and benign, sporadic phaeochromocytomas. International Journal of Cancer 79 537-540.

Xing M, Vasko V, Tallini G, Larin A, Wu G, Udelsman R, Ringel MD, Ladenson PW \& Sidransky D 2004 BRAF 
T1796A transversion mutation in various thyroid neoplasms. Journal of Clinical Endocrinology and Metabolism 89 1365-1368.

Xu X, Quiros RM, Gattuso P, Ain KB \& Prinz RA 2003 High prevalence of BRAF gene mutation in papillary thyroid carcinomas and thyroid tumor cell lines. Cancer Research $\mathbf{6 3}$ 4561-4567.
Zhao J, de Krijger RR, Meier D, Speel EJ, Saremaslani P, Muletta-Feurer S, Matter C, Roth J, Heitz PU \& Komminoth P 2000 Genomic alterations in well-differentiated gastrointestinal and bronchial neuroendocrine tumors (carcinoids): marked differences indicating diversity in molecular pathogenesis. American Journal of Pathology 157 1431-1438. 